\title{
Exploring faculty reading and research behaviors in a public and a private university: Case-study Cuenca, Ecuador
}

\author{
Hubert B. Van Hoof ${ }^{1}$, Ana Cueva Navas ${ }^{2}$, Aileen Fan ${ }^{1}$, Karina Farfán Pacheco ${ }^{3}$, Miguel-Angel \\ Galarza Cordero ${ }^{2}$ \\ ${ }^{1}$ School of Hospitality Management, Penn State University, PA, USA. \\ ${ }^{2}$ Facultad de Ciencias de la Hospitalidad, Universidad de Cuenca, Cuenca, Ecuador. \\ ${ }^{3}$ Facultad de Psicología, Universidad del Azuay, Cuenca, Ecuador. \\ Autor para correspondencia: hbv1@psu.edu
}

Fecha de recepción: 2 de marzo 2014 - Fecha de aceptación: 12 de abril 2014

\begin{abstract}
In light of recent changes in Ecuador's higher education system that are aimed at enhancing the universities' academic performance and thereby their ability to help address the country's socioeconomic problems and contribute to the country's growth, this article reports on a study that investigated the research and reading behaviors of faculty members in a private and a public university in Cuenca, Ecuador. An analysis of the self-reported reading and research behaviors of 129 professors in both universities revealed that professors are poorly prepared to conduct research and are even less familiar with publishing its results in peer reviewed journals. Hardly any differences in faculty reading and research behaviors were observed between both universities. Additionally, no significant differences in research productivity were detected between those professors who held graduate degrees and those who did not. The article concludes that greater research and publication expectations need to be placed on professors with advanced degrees, in particular those holding doctoral degrees. The latter should take on leadership roles in the universities' research efforts. However, to make this happen Ecuador's universities need to take steps to reduce faculty involvement in teaching, provide adequate resources and create an infrastructure that is truly conducive to research growth. This process will be further enhanced if a reward system for research and publication is in place.
\end{abstract}

Keywords: Faculty reading, research behaviors, exploratory investigation, research and publication productivity.

\section{RESUMEN}

En vista de los recientes cambios en el sistema de educación superior del Ecuador que están dirigidos a mejorar el rendimiento académico de las universidades y por lo tanto su capacidad para ayudar a resolver los problemas socio-económicos del país y contribuir a su crecimiento, este artículo informa sobre un estudio que investigó las actitudes de investigación y de lectura de los miembros del profesorado en una universidad privada y pública en Cuenca, Ecuador. Un análisis auto-centrado de las conductas de lectura y de investigación de 129 profesores de ambas universidades reveló que los profesores no están bien preparados para llevar a cabo la investigación y no están incluso muy familiarizados con el proceso de publicación de sus resultados en revistas revisadas por pares académicos. Casi no se observaron diferencias en las actitudes de lectura y de investigación entre los docentes de ambas universidades. Además, no se detectaron diferencias significativas en la productividad de la investigación entre los profesores que llevan a cabo estudios de postgrado y los que no lo hicieron. El artículo concluye que las mayores expectativas de investigación y de publicación deben ser colocadas en los profesores con grados avanzados, en particular, en los profesores con doctorados. Estos últimos deben asumir roles de liderazgo en los esfuerzos de investigación de las universidades. No obstante, para que esto suceda, las universidades ecuatorianas deben tomar medidas para reducir la participación del profesorado en la enseñanza, proporcionar los 
recursos adecuados y crear una infraestructura que sea verdaderamente propicia para el crecimiento de la investigación. Este proceso también se verá fortalecido con el establecimiento de un sistema de incentivos para la investigación y la publicación.

Palabras clave: Actitud de lectura de profesores, actitud de investigación, investigación exploratoria, productividad de investigación y de publicación.

\section{INTRODUCTION}

The research productivity of Ecuador's universities is extremely low, representing only $0.2 \%$ of the world's research output and only 4\% of Latin America's publication productivity (SCImago Research Group, 2014). They were steeped in century-old teaching traditions that emphasized the social sciences till the mid-nineteenth century and have focused their efforts primarily on shaping the country's future workforce and on providing its government offices, industries and schools with teachers, chemists, engineers, analysts and managers since then. Ferrari and Contreras (2008), in discussing the larger Latin-American academic environment, attribute this paucity of research output on the continent to several factors: a small number of university-educated graduates in relation to the overall population, a low number of research projects that are instigated and executed in university settings and low budgets for science and technology. They state that South-America's universities lack resources and research facilities and that there is only a limited supply of postgraduates to continue and enhance the research effort.

Even though many Ecuadorian professors hold advanced degrees, those degrees are not researchbased, which means that very few of them are properly educated to conduct research and publish its outcomes. Many doctoral degrees are concentrated in a few areas of study such as medicine, science and engineering. In the social sciences in particular the lack of research competency is glaring. This situation is worsened by the fact that Ecuador's professors tend to spend many hours in the classroom teaching undergraduate students and therefore have little or no time to do research. The university environment they work in has shown little true appreciation of the value of research, as exemplified by the lack of concrete support and stimulation for those who are interested in and capable of doing research. This particular trend is further exacerbated by the fact that many professors who have advanced, research-based degrees either end up in administrative positions or (voluntarily or involuntarily) fall back into comfortable teaching routines.

As a country, Ecuador is not only faced with a teaching-oriented higher education system that lacks research competency, but also with considerable societal problems such as income inequality, rural poverty, poor social mobility and threats to vulnerable ecosystems. In order to move the country from a primarily agricultural society to a more balanced, modern mixed-economy and a more prominent global position, Ecuador's government is looking for its universities to take a leadership role in addressing its societal problems, a role that universities the world over have played for decades, if not centuries (Feyen and Van Hoof, 2013). Aware of the limited research capacity of its university system and the low qualifications of its professors, the Ecuadorian government recently implemented several rapid and invasive changes to the universities' funding structures, reporting lines, admission policies, faculty qualifications and research responsibilities. Both the speed with which those changes were introduced and the dramatic impact they have had on administrators, faculty and students are indicative of the sense of urgency that exists in government circles about changing the role of the universities in Ecuadorian society. Some of those changes came in the form of mandates to professors already employed in higher education; others, such as the grant program for graduate studies, are optional. Some changes affected the universities and others directly impacted individual faculty members; some met with scorn and resistance, others were welcomed wholeheartedly, and whereas it is to be expected that some of the changes will lead younger faculty members to seek graduate degrees, they might also cause older faculty members to seek retirement as early as possible.

The two landmarks initiatives that anchored those rapid and dramatic changes were the New Constitution of 2008 and the 2010 Higher Education Law. The 2008 Constitution established people's rights to free education and gave the central government a much greater regulatory and budgetary role 
in the higher education system by abolishing a tuition fee structure that had partially funded the country's universities since their origins. It took away much of the universities' autonomy and placed the government largely in control of student admissions (Van Hoof et al., 2013). The 2010 Higher Education Law further increased the central regulation of the university system, with the specific intent to align the universities' research and teaching efforts more closely with the country's social and economic development needs. The law defined faculty qualifications and revised faculty employment contracts. It mandated that all faculty members teaching in the university system after 2010 needed to have at least a master's degree and professors were presented with a 7-year deadline to obtain doctoral degrees. The intent behind the mandates is clear: better educated professors teach at higher levels, will be able to conduct research and will have the ability to contribute to solving some of the country's problems and enhance Ecuador's role on the global platform.

Both laws included the expectation that universities should take a more active role in enhancing the quality and quantity of their research output and that they should work on improving the research qualifications of their professors and the research infrastructure within the institution. The 2010 Higher Education Law stipulated that for a university to be considered a "research" university by $2017,70 \%$ of its professors must hold doctorates. For it to be recognized as a "research-teaching" institution, this benchmark lies at 40\% of all professors (Van Hoof et al., 2013a). Yet, given the low number of doctorates in the system (at present that number is less than $5 \%$ of full-time faculty at the University of Cuenca, for instance), the limited opportunities available to pursue research-based graduate degrees and despite the initial support from foreign experts brought in through the innovative Prometeo grant program, these are tall orders. There is no denying that higher education in Ecuador is in need of tremendous changes, yet the timelines that were set in place for these changes will most likely prove insurmountable obstacles for most universities since they are based on unrealistic expectations of professors who have never been engaged in research. In a long-term strategic planning process as this is, it is not bad to have bold, far-reaching goals. Yet, for a plan like this to work, it also needs to have realistic expectations and attainable timelines. A plan that is overly ambitious and that is not based on a solid assessment of the existing situation does not motivate, it confuses at best and it demotivates or even alienates at worst.

This article reports on the assessment of the reading and research behaviors of professors at a public and a private university in Cuenca, Ecuador. The study was exploratory in nature and solely intended to collect and report initial data that could be helpful in determining whether the timelines that are put in place for Ecuador's professors are feasible. The outcomes could assist both universities, as well as other Ecuadorian universities, in stimulating their professors' involvement in the research process by providing them with incentives and concrete support as the conclusion suggests. Furthermore, its results can also be tied to students' reading behaviors and research interests. If professors do not spend much time and effort on reading and research, how can they be expected to enhance their students' reading behaviors and stimulate student appreciation of research, thereby raising the bar for higher education in Ecuador overall?

\section{A BRIEF SYNOPSIS OF RELEVANT LITERATURE}

Scholars have investigated and discussed how to assess and enhance faculty research extensively and the literature on the topic is considerable. For example, articles on the assessment of research effectiveness have been published by field of study (Dudar and Lewis, 1998; Hasselback et al., 2000; Wiliamson and Cable, 2003; Bland et al., 2005) and by country (Teodorescu, 2000; Smeby and Try, 2005). Studies on faculty research output have been done based on such variables as faculty gender (Chen \& Zhao, 2013), personality type (Taylor et al., 1984), family situation (Sax et al., 2002), race (Bellas and Toutkoushian, 2000), faculty status (Hekelman et al., 1995; Fien and Blackburn, 1996; Perry et al., 2000), academic origin and affiliation (Sa, 2008; Long et al., 2009), desire to be promoted (Fien, 2000; Fien, 2008), perceived rewards (Chen et al., 2004; Chen et al., 2006) and its relationship to teaching (Blackburn et al., 1991; Prince et al., 2007). 
Yet, in combination with modifiers such as "South-America", "Latin-America", or "Ecuador" a review of English language literature comes up negative. This does not mean there are no publications about the topic: there are several in the Spanish language on similar topics, primarily related to the Spanish academic environment, such as Valarino (2001), Sierra, (2009), Buela-Casal et al. (2011), Delgado and Fernandez-Llera (2012) and Olivas et al. (2012). However, it does mean that the literature on the topics of research productivity and research performance in South American higher education in the English language is very scarce. This makes the following report in English on the research and reading behaviors of faculty members in two Ecuadorian universities even more relevant.

\section{METHODOLOGY AND DATA COLLECTION}

\subsection{The instrument}

Given the scarcity of English literature on the topic related to the South American setting, the nature of the study reported here was primarily exploratory. The survey was designed to determine professors' reading and research behaviors, and was partially inspired by an analogue study on the assessment of the reading behaviors of students in both universities (Van Hoof et al., 2013b). In comparing professors' behaviors at a public and a private university in Cuenca, the study hoped to find out 1) how much professors read in preparation for their classes and in connection with their research interests; 2) what factors might influence their research behaviors; 3) if any of the observed differences of behavior between professors at the two universities were significantly different; and 4) what universities might do to stimulate the research and reading activities of their professors.

The study used a survey designed to investigate these issues at the University of Azuay (UDA) and the University of Cuenca (UC) in Cuenca, Ecuador. In the SIR Iberoamericano Ranking (SCImago Research Group, 2014) of Ecuadorian universities, UC is ranked $8^{\text {th }}$ and UDA is ranked $16^{\text {th }}$ among the 40 universities and research institutes that published at least one manuscript in the period 2008-2012 in journals registered in the Scopus database. Both are regional universities: the UC is representative of the lower end of the top 10 universities in the country with regard to publication activity and UDA is situated at the top of the bottom group of institutions that hardly publish any research in any of the journals registered by Scopus. Below this second group there are several other universities in Ecuador that do not get one manuscript published in any of the registered journals. They might publish, but their research findings are mainly presented in non-refereed, Spanish manuscripts that are published at the local, regional or national levels. Both institutions are situated in the middle of the rankings: there are certainly several universities that publish more, yet there are even more universities that publish considerably less, making them representative of common research behavior and activity nationwide.

Upon completion of the draft instrument, the survey was presented to a pilot group of four professors in different departments at the University of Cuenca. Based on their input, several modifications were made that not only enhanced the clarity of the questions but also resulted in the inclusion of several additional issues. Pilot group feedback indicated that the survey would take approximately 15 minutes to complete. A statement on the first page of the survey encouraged respondents to answer all questions carefully and honestly since they were assured of the confidentiality of the process. Their right of refusal to participate was clearly stated in the questionnaire. In order to achieve the highest possible response rate and the widest variability of responses, it was decided to use a hard-copy format and for participants to self-administer the survey.

The survey consisted of three parts: the first part asked respondents to share demographic information such as their age, gender, faculty position, teaching experience, years worked at the university and their own education levels. The second part looked into respondents' reading behaviors, in relation to teaching, research and casual (non-academic) efforts. The third part investigated the respondents' research efforts and research skills in greater detail. 


\subsection{Data collection and limitations}

The survey was conducted during the months of September and October 2013. In an effort to achieve the highest possible response rate and cognizant of the sensitivity of the subject matter, the sampling procedures were not random and surveys were distributed to all faculties in both universities with the request to be distributed among the professors. At the end of the two-month data collection period, 75 surveys were collected at the University of Cuenca out of a population of 497 full-time professors, 266 half-time professors and 312 part-time professors (UC Dirección de Talento Humano, 2013). At the University of Azuay, 54 surveys were collected out of a population of 160 full-time professors and 240 part-time professors in the Faculties of Science and Technology, Philosophy, Business Administration, and Law. The low response of faculty in both institutions is already very indicative of the low to moderate interest faculty has in research related activities. The main interest of most staff is still oriented to classical classroom teaching.

The main limitation of this study was that its results cannot be generalized beyond the two universities investigated because respondent selection was not random and the study was limited to professors at UC and UDA. Furthermore, the surveys were self-reported and the researchers had to trust that respondents felt comfortable enough about the guaranteed confidentiality that they would answer the questions truthfully. Because the surveys did not include a reference to the individual faculties in the universities for reasons of confidentiality, this report cannot make any assumptions about the academic origins of the respondents. However, the researchers feel comfortable in stating that the results of the study are suggestive of broader tendencies among professors in both universities and, to a lesser extent, of tendencies around the country.

This manuscript first discusses the results of the descriptive and comparative analyses of faculty reading behaviors. It then explores the outcomes of the various analyses related to faculty research behaviors. In its conclusion the paper goes into some dominant issues and suggests ways in which Ecuador's universities could contribute to enhancing the research output of their professors.

\section{RESULTS}

\subsection{Demographic information}

A majority $(58,9 \%)$ of the respondents to the survey were males, more so at UDA $(64,8 \%)$ than at UC $(54,7 \%)$. The average age of the respondents was about 42 years. Respondents at UC had more teaching experience and had worked at the university a little longer than their peers at UDA. A majority of the respondents $(64,0 \%)$ held graduate level degrees, $56,9 \%$ at UC and $73,6 \%$ at UDA. Respondents at UC taught fewer hours than those at UDA and held somewhat higher faculty appointments than their colleagues at UDA. Almost half $(47,3 \%)$ of the respondents had a full-time teaching assignment (see Table 1).

\subsection{Faculty reading behaviors}

\subsubsection{Descriptive analysis and results}

When asked if, and how much, they read in preparation for their classes every week, a large majority of the respondents $(92,6 \%)$ stated that they spent an average of 10 hours per week doing so. Most respondents $(88,6 \%)$ mentioned they also spent time on casual (non-academic) reading, but considerably less (about 5,5 hours weekly) than on their academic reading. Faculty members at UDA reported slightly higher averages than professors at UC (see Table 1).

\subsubsection{Comparative analysis and results}

In order to determine if any of the observed differences between the various groups in the survey were significant, the study then conducted various comparative analyses by means of T-tests to determine if any of the observed differences in the descriptive data between various groups of respondents (UC vs. UDA, male vs. female, low education level vs. high education level) were significant. In all instances, 
the null hypotheses assumed that the population means were equal and the alpha level was set at 0,05 , common in social science research.

The effect of university origin

A comparison of professors at UDA and UC only found two significant differences between the two groups. There was a marginally significant $(0,056)$ difference in education levels between professors at UDA and professors at UC: professors at the University of Azuay had significantly higher education levels than professors at UC. The other observed significant difference at the 0,000 level was that professors at UDA taught significantly more hours per week in the classroom than their peers at UC. No significant differences were observed between the two groups with regard to their reading behaviors (see Table 2).

Table 1. Faculty demographics and general reading behaviors: Descriptive statistics.

\begin{tabular}{|c|c|c|c|c|c|c|}
\hline \multirow{2}{*}{$\begin{array}{c}\text { University } \\
\text { Gender }\end{array}$} & \multicolumn{2}{|c|}{$\begin{array}{l}\text { Universidad de } \\
\text { Cuenca (UC) }\end{array}$} & \multicolumn{2}{|c|}{$\begin{array}{l}\text { Universidad del } \\
\text { Azuay UDA) }\end{array}$} & \multicolumn{2}{|c|}{ All } \\
\hline & $\mathrm{N}^{*}$ & $\%$ & $\mathrm{~N}^{*}$ & $\%$ & $\mathrm{~N}^{*}$ & $\%$ \\
\hline Male & 41 & 54,7 & 35 & 64,8 & 76 & 58,9 \\
\hline Female & 34 & 45,3 & 18 & 33,3 & 52 & 40,3 \\
\hline Age and experience (in years) & Mean & STD & Mean & STD & Mean & STD \\
\hline Age & 42,40 & 11,27 & 42,56 & 10,52 & 42,47 & 10,92 \\
\hline Experience at particular university & 11,09 & 11,64 & 10,65 & 9,07 & 10,65 & 9,07 \\
\hline Average teaching hours & 14,09 & 5,42 & 17,94 & 6,25 & 15,73 & 6,07 \\
\hline Total university teaching & 13,69 & 12,39 & 10,48 & 1,43 & 11,59 & 1,02 \\
\hline Education level & $\mathrm{N}$ & $\%$ & $\mathrm{~N}$ & $\%$ & $\mathrm{~N}$ & $\%$ \\
\hline Bachelor \& lower & 31 & 43,1 & 14 & 26,4 & 45 & 36,0 \\
\hline Master/Doctorate & 41 & 56,9 & 39 & 73,6 & 80 & 64,0 \\
\hline Type of appointment & $\mathrm{N}$ & $\%$ & $\mathrm{~N}$ & $\%$ & $\mathrm{~N}$ & $\%$ \\
\hline Titular - Principal & 26 & 34,7 & 15 & 27,8 & 41 & 31,8 \\
\hline Titular - Agregado & 10 & 13,3 & 3 & 5,6 & 13 & 10,1 \\
\hline Titular - Auxiliar & 2 & 2,7 & 10 & 18,5 & 12 & 9,3 \\
\hline Invitado & 1 & 1,3 & 1 & 1,9 & 2 & 1,6 \\
\hline Honorario & 0 & 0,0 & 1 & 1,9 & 1 & 0,8 \\
\hline Contratado & 35 & 46,7 & 22 & 40,7 & 57 & 44,2 \\
\hline Teaching time & $\mathrm{N}$ & $\%$ & $\mathrm{~N}$ & $\%$ & $\mathrm{~N}$ & $\%$ \\
\hline Tiempo parcial & 19 & 25,3 & 18 & 33,3 & 37 & 28,7 \\
\hline Medio tiempo & 19 & 25,3 & 10 & 18,5 & 29 & 22,5 \\
\hline Tiempo completo & 36 & 48,0 & 25 & 46,3 & 61 & 47,3 \\
\hline Dedicación exclusiva & 1 & 1,3 & 1 & 1,9 & 2 & 1,6 \\
\hline Course related reading & $\mathrm{N}$ & $\%$ & $\mathrm{~N}$ & $\%$ & $\mathrm{~N}^{*}$ & $\%$ \\
\hline Yes & 64 & 92,8 & 49 & 92,5 & 113 & 92,6 \\
\hline No & 5 & 7,2 & 4 & 7,5 & 9 & 7,4 \\
\hline Weekly course related reading & Mean & 9,91 & Mean & 10,15 & Mean & 10,02 \\
\hline Casual reading & $\mathrm{N}$ & $\%$ & $\mathrm{~N}$ & $\%$ & $\mathrm{~N}^{*}$ & $\%$ \\
\hline Yes & 64 & 91,4 & 45 & 84,9 & 109 & 88,6 \\
\hline No & 6 & 8,6 & 8 & 15,1 & 14 & 11,4 \\
\hline Weekly casual reading hours & Mean & 5,10 & Mean & 6,14 & Mean & 5,54 \\
\hline
\end{tabular}

Legend: * = Totals not adding up to 129 (All), to 75 (UC) or to 54 (UDA) are indicative of missing values in the category; $\%$ expresses share of total number of valid answers obtained in the category.

The effect of gender on reading behavior

A second analysis then looked at whether there were significantly different reading behaviors between male and female professors in the sample. As Table 3 shows male professors were significantly more likely to engage in academic reading than female professors (see Table 3). There were no significant differences between the two groups in hours spent reading for academic or personal reasons. 
Table 2. Comparison between Universities (UC vs. UDA).

\begin{tabular}{|c|c|c|c|c|c|c|c|c|c|}
\hline Descriptive variables & Univ. & $\mathrm{N}$ & $\mathrm{M}$ & SD & MD & SEd & $\mathrm{t}$ & $\mathrm{df}$ & $\mathrm{p}$ \\
\hline \multirow[t]{2}{*}{ Appointment type } & $\mathrm{UC}$ & 74 & 3,59 & 2,352 & - & \multirow{2}{*}{0,413} & - & \multirow{2}{*}{124} & \multirow{2}{*}{0,813} \\
\hline & UDA & 52 & 3,69 & 2,174 & 0,098 & & 0,237 & & \\
\hline \multirow[t]{2}{*}{ Teaching type } & $\mathrm{UC}$ & 75 & 2,25 & 0,856 & \multirow{2}{*}{0,087} & \multirow{2}{*}{0,158} & \multirow{2}{*}{0,548} & \multirow{2}{*}{127} & \multirow{2}{*}{0,585} \\
\hline & UDA & 54 & 2,17 & 0,927 & & & & & \\
\hline \multirow[t]{2}{*}{ Gender } & $\mathrm{UC}$ & 75 & 0,45 & 0,501 & \multirow{2}{*}{0,114} & \multirow{2}{*}{0,088} & \multirow{2}{*}{1,289} & \multirow{2}{*}{126} & \multirow{2}{*}{0,200} \\
\hline & UDA & 53 & 0,34 & 0,478 & & & & & \\
\hline \multirow[t]{2}{*}{ Age } & $\mathrm{UC}$ & 75 & 42,40 & 11,273 & - & \multirow{2}{*}{1,957} & & \multirow{2}{*}{127} & \multirow{2}{*}{0,937} \\
\hline & UDA & 54 & 42,56 & 10,516 & 0,156 & & 0,079 & & \\
\hline \multirow[t]{2}{*}{ Education level } & $\mathrm{UC}$ & 72 & 0,57 & 0,499 & - & \multirow{2}{*}{0,086} & - & \multirow{2}{*}{123} & \multirow{2}{*}{0.056} \\
\hline & UDA & 53 & 0,74 & 0,445 & 0,166 & & 1,929 & & \\
\hline \multirow{2}{*}{$\begin{array}{l}\text { Teaching } \\
\text { experience }\end{array}$} & $\mathrm{UC}$ & 75 & 13,69 & 12,391 & \multirow{2}{*}{0,890} & \multirow{2}{*}{2,076} & \multirow{2}{*}{0,429} & \multirow{2}{*}{127} & \multirow{2}{*}{0,669} \\
\hline & UDA & 54 & 12,80 & 10,478 & & & & & \\
\hline \multirow{2}{*}{$\begin{array}{l}\text { University } \\
\text { experience }\end{array}$} & $\mathrm{UC}$ & 75 & 11,09 & 11,640 & \multirow{2}{*}{0,438} & 1000 & & & \\
\hline & UDA & 54 & 10,65 & 9,073 & & 1,900 & 0,230 & 121 & 0,818 \\
\hline Teaching hours & $\mathrm{UC}$ & 70 & 14,09 & 5,418 & - & 1050 & - & & \\
\hline & UDA & 52 & 17,94 & 6,248 & 3,849 & $1,0 \supset 9$ & 3,634 & 120 & 0,000 \\
\hline Course related & UC & 69 & 0,07 & 0,261 & - & 0048 & - & 120 & 0050 \\
\hline reading & UDA & 53 & 0,08 & 0,267 & 0,003 & 0,048 & 0,062 & 120 & טני,ט \\
\hline Weekly course & $\mathrm{UC}$ & 70 & 9,10 & 6,839 & - & 1439 & - & & \\
\hline related reading & UDA & 53 & 10,15 & 9,120 & 0,237 & 1,439 & 0,165 & 121 & 0,870 \\
\hline Casual reading & $\mathrm{UC}$ & 70 & 0,09 & 0,282 & - & 0058 & - & 121 & 0263 \\
\hline & UDA & 53 & 0,15 & 0,361 & 0,065 & 0,050 & 1,125 & 121 & 0,203 \\
\hline Weekly casual & $\mathrm{UC}$ & 68 & 5,10 & 5,205 & - & 1084 & - & 127 & 0338 \\
\hline reading hours & UDA & 51 & 6,14 & 6,615 & 1,042 & 1,004 & 0,961 & 121 & ס,550 \\
\hline
\end{tabular}

Legend: Univ. = university; UC coded as 0, UDA coded as 1; Bachelor \& below coded as 0, Master \& above coded as 1; $\mathrm{N}=$ number; $\mathrm{M}=$ mean; $\mathrm{SD}=$ standard deviation; $\mathrm{MD}=$ mean difference; $\mathrm{SEd}=$ standard error difference; $\mathrm{t}=\mathrm{t}$-value; $\mathrm{df}=$ degrees of freedom; $\mathrm{p}=$ sigma (2-tailed).

Table 3. Comparison between genders (male vs. female).

\begin{tabular}{lrrrrr}
\hline Descriptive variables & MD & SEd & t & df & p \\
\hline Course related reading & $-0,101$ & 0,046 & $-2,196$ & 119 & 0,030 \\
\hline Weekly course related reading & $-0,149$ & 1,473 & $-0,101$ & 120 & 0,920 \\
\hline Casual reading & 0,000 & 0,058 & 0,005 & 120 & 0,996 \\
\hline Weekly casual reading hours & 0,965 & 1,113 & 0,867 & 116 & 0,388 \\
\hline
\end{tabular}

Legend: Male coded as 0 , Female coded as 1; "Yes" coded as 0 , "No" coded as 1.

The effect of education level

A third comparison examined whether professors with higher levels of education were more inclined to read than those with lower levels of education. The study found no significant differences of behavior; professors with higher education levels were only marginally less likely to read casual readings, yet did not read significantly more than their peers when it came to academic reading (See Table 4).

Table 4. Comparison between education levels (Bachelors \& below vs. Masters \& above).

\begin{tabular}{lrrrrr}
\hline Descriptive variables & MD & SEd & $\mathrm{t}$ & $\mathrm{df}$ & $\mathrm{p}$ \\
\hline Course related reading & 0,020 & 0,0511 & 0,402 & 116 & 0,688 \\
\hline Weekly course related reading & 1,481 & 1,501 & 0,986 & 117 & 0,326 \\
\hline Casual reading & $-0,118$ & 0,060 & $-1,947$ & 117 & 0,054 \\
\hline Weekly casual reading hours & 0,157 & 1,137 & 0,138 & 113 & 0,890 \\
\hline
\end{tabular}

Further analysis of reading behaviors

A final analysis was done based on appointment level (principal vs. agregado vs. auxiliar) and time teaching (tiempo parcial vs. tiempo medio vs. tiempo completo). In this case, the study used Analysis 
of Variance (ANOVA) to compare the three groups and found that neither appointment level nor time teaching had any significant impact on the professors' reading behaviors.

\subsection{Faculty research behavior}

\subsubsection{Descriptive analysis and results}

More important perhaps than information about faculty reading behaviors is information about the professors' research and publication efforts. The third part of the survey looked into this and was divided into four sub-groups: 1) questions about research courses taken; 2) questions about reading and using literature for research purposes (including an assessment of foreign language skills); 3) a question about the professors' actual research/publication activities; and 4) questions regarding access to literature.

As Table 5 shows, only $42,6 \%$ of the respondents indicated that they had taken a research methods course outside the university before. This number decreased to $27,9 \%$ when it came to a research methods course taken inside their university. More UDA professors than UC professors had taken a research methods course outside the university, which could be attributed to the significantly

Table 5. Faculty research related activities: Descriptive statistics.

\begin{tabular}{|c|c|c|c|c|c|c|}
\hline \multirow[t]{2}{*}{ "Yes" selected } & \multicolumn{2}{|c|}{$\begin{array}{l}\text { Universidad de } \\
\text { Cuenca (UC) }\end{array}$} & \multicolumn{2}{|c|}{$\begin{array}{l}\text { Universidad del } \\
\text { Azuay (UDA) }\end{array}$} & \multicolumn{2}{|c|}{ All } \\
\hline & $\mathrm{N}$ & $\%$ & $\mathrm{~N}$ & $\%$ & $\mathrm{~N}$ & $\%$ \\
\hline $\begin{array}{l}\text { Taken research methods course - } \\
\text { Outside }\end{array}$ & 28 & 37,3 & 27 & 50,0 & 55 & 42,6 \\
\hline $\begin{array}{l}\text { Taken research methods course - } \\
\text { Inside }\end{array}$ & 20 & 26,7 & 16 & 29,6 & 36 & 27,9 \\
\hline Personal need for methods course & 55 & 73,3 & 47 & 87,0 & 102 & 79,1 \\
\hline $\begin{array}{l}\text { University needs to offer methods } \\
\text { course }\end{array}$ & 61 & 81,3 & 49 & 90,7 & 110 & 85,3 \\
\hline Read research literature & 65 & 86,7 & 50 & 92,6 & 115 & 89,1 \\
\hline Read textbook & 46 & 61,3 & 37 & 68,5 & 83 & 64,3 \\
\hline Read academic article & 52 & 69,3 & 42 & 77,8 & 94 & 72,9 \\
\hline Read non-academic article & 29 & 38,7 & 11 & 22,4 & 40 & 32,0 \\
\hline Read online material & 54 & 72,0 & 40 & 74,1 & 94 & 73,1 \\
\hline Non-Spanish research reading & 64 & 85,3 & 42 & 77,8 & 106 & 82,2 \\
\hline \multicolumn{7}{|l|}{ English language control } \\
\hline Not at all & 3 & 4,0 & 5 & 9,3 & 8 & 6,6 \\
\hline Poor & 11 & 14,7 & 9 & 16,7 & 20 & 16,6 \\
\hline Reasonable & 24 & 32,0 & 19 & 35,2 & 43 & 35,5 \\
\hline Good & 18 & 24,0 & 12 & 22,2 & 30 & 24,8 \\
\hline Excellent/Fluent & 13 & 17,3 & 7 & 13,0 & 20 & 16,5 \\
\hline Academic publication subscription & 24 & 32,0 & 14 & 25,9 & 38 & 29,5 \\
\hline \multicolumn{7}{|l|}{ Publication \& presentation } \\
\hline Presentation at academic & 36 & 48,0 & 21 & 39,8 & 57 & 44,4 \\
\hline Non-academic article(s) & 31 & 41,3 & 26 & 48,1 & 57 & 44,4 \\
\hline Invited presentation(s) & 32 & 42,7 & 16 & 29,6 & 48 & 37,5 \\
\hline Presentation at non-academic & 28 & 37,3 & 13 & 24,1 & 41 & 31,2 \\
\hline Textbook & 21 & 28,0 & 13 & 24,1 & 34 & 26,4 \\
\hline Refereed indexed article(s) & 20 & 26,7 & 12 & 22,2 & 32 & 24,8 \\
\hline Textbook chapter(s) & 14 & 18,7 & 7 & 13,0 & 21 & 16,3 \\
\hline Book review & 12 & 16,0 & 6 & 11,1 & 18 & 14,0 \\
\hline Enough access to literature & 30 & 40,0 & 30 & 55,6 & 60 & 46,5 \\
\hline Enough access to digital literature & 31 & 41,3 & 36 & 66,7 & 67 & 51,9 \\
\hline University library usage & 32 & 42,7 & 25 & 46,3 & 57 & 44,2 \\
\hline Weekly research related reading & Mean & 6,1 & Mean & 5,1 & Mean & 5,7 \\
\hline \multirow[t]{3}{*}{ hours } & STD & 4,9 & STD & 5,3 & STD & 5,1 \\
\hline & Min & 1,0 & Min & 1,0 & Min & 1,0 \\
\hline & Max & 20,0 & Max & 30,0 & Max & 30,0 \\
\hline
\end{tabular}


higher number of advanced degrees at UDA. Large majorities among the respondents felt that they needed a research methods course $(79,1 \%)$ and that the university needed to offer such a course inhouse $(85,3 \%)$, with UDA professors expressing greater needs for such courses than their counterparts at UC (see Table 5).

A large majority $(89,1 \%)$ of the respondents also indicated that they had read literature related to research before, with $85,3 \%$ of the professors at UC stating they had read literature in a language other than Spanish, as compared to $77,8 \%$ of the professors at UDA. Academic articles $(72,9 \%)$ and online materials $(73,1 \%)$ were the most commonly read forms of literature (See Table 5). With regard to their reported control of the English language, 6,2\% of the respondents rated their control as "not at all," $15,5 \%$ felt that it was "poor", $33,3 \%$ rated it as "reasonable", $23,3 \%$ rated it as "good" and $15,5 \%$ of the respondents said their control was "excellent/fluent." Overall, UC professors indicated a better control of the English language than UDA professors. About one-third $(29,5 \%)$ of the respondents stated they subscribed to an academic publication.

With regard to their own publication and presentation efforts, non-academic articles $(44,4 \%)$ and presentations at academic conferences $(44,4 \%)$ were most common, followed by invited presentations (37,5\%). Only $24,8 \%$ of the respondents had written a refereed, indexed article before. As Table 5 shows, professors at UDA had published considerably less than their peers at UC (See Table 5). When asked to rate the access they had to research literature, UDA professors were much more positive than their peers at UC; whereas a majority at UDA stated they had enough access to literature $(55,6 \%)$ and digital literature $(66,7 \%)$, only about $40 \%$ of the UC professors agreed they had sufficient access. Less than half the total respondents indicated they used the university library (See Table 5).

Finally, when asked how many hours a week they spent on research-related activities, UC professors stated they spent an average of 6,1 hours on research activities and UDA professors indicated they spent an average of 5,1 hours (See Table 5).

\subsubsection{Comparative analysis and results}

Similar to the reading category, the study then conducted various comparative analyses by means of Ttests and ANOVAs to determine if any of the observed differences in the descriptive data between the groups of respondents (UC vs. UDA, male vs. female, low education level vs. high education level) were significant. The null hypotheses once again assumed that the population means were equal and the alpha level was set at 0,05 .

\section{The effect of university origin and gender}

Even though the descriptive results as described in Table 5 hinted at some differences between professors at UC and professors at UDA, the study did not find any of those differences to be statistically significant (Table 6). Similarly, the study did not find any significant differences based on gender (see Table 7).

The most striking observations as summarized in both these tables were: 1) the high percentage of respondents in both universities asking for the university to offer research method courses, notwithstanding that a moderate to high percentage of respondents possess a master or higher degree; 2) professors investing little time in reading research literature independent of their gender, with most of their reading time invested in course-related literature; 3) professors reading little non-Spanish research literature, which means that they are not aware of the scientific information published in English journals, which represent over $90 \%$ of all peer reviewed journals; and 4) the respondents claims of control of the English language as opposed to the fact that they hardly read English manuscripts or publish research results internationally. This leads one to doubt the credibility of their claim that they have good control of the English language. 
Table 6. Research related activities: Comparison between Universities (UC vs. UDA).

\begin{tabular}{|c|c|c|c|c|c|c|c|c|c|}
\hline Descriptive variables & Univ. & $\mathrm{N}$ & $\mathrm{M}$ & SD & $\mathrm{MD}$ & SEd & $\mathrm{t}$ & $\mathrm{df}$ & $\mathrm{p}$ \\
\hline \multirow{2}{*}{$\begin{array}{l}\text { Taken research } \\
\text { methods course }\end{array}$} & $\mathrm{UC}$ & 71 & 0,61 & 0,492 & \multirow{2}{*}{0,125} & \multirow{2}{*}{0,091} & \multirow{2}{*}{1,375} & \multirow{2}{*}{121} & \multirow{2}{*}{0,172} \\
\hline & UDA & 52 & 0,48 & 0,505 & & & & & \\
\hline \multirow{2}{*}{$\begin{array}{l}\text { Taken research } \\
\text { methods course }\end{array}$} & $\mathrm{UC}$ & 65 & 0,69 & 0,465 & \multirow{2}{*}{0,000} & \multirow{2}{*}{0,087} & \multirow{2}{*}{0,000} & \multirow{2}{*}{115} & \multirow{2}{*}{1,000} \\
\hline & UDA & 52 & 0,69 & 0,466 & & & & & \\
\hline \multirow{2}{*}{$\begin{array}{l}\text { Personal need for } \\
\text { method course }\end{array}$} & $\mathrm{UC}$ & 67 & 0,18 & 0,386 & \multirow{2}{*}{0,083} & \multirow{2}{*}{0,065} & \multirow{2}{*}{1,281} & \multirow{2}{*}{117} & \multirow{2}{*}{0,203} \\
\hline & UDA & 52 & 0,10 & 0,298 & & & & & \\
\hline \multirow{2}{*}{$\begin{array}{l}\text { University needs to } \\
\text { offer methods course }\end{array}$} & $\mathrm{UC}$ & 65 & 0,06 & 0,242 & \multirow{2}{*}{0,004} & \multirow{2}{*}{0,045} & \multirow{2}{*}{0,086} & \multirow{2}{*}{115} & \multirow{2}{*}{0,931} \\
\hline & UDA & 52 & 0,06 & 0,235 & & & & & \\
\hline Read research & $\mathrm{UC}$ & 69 & 0,06 & 0,235 & \multirow{2}{*}{0,020} & \multirow{2}{*}{0,040} & \multirow{2}{*}{0,486} & \multirow{2}{*}{119} & \multirow{2}{*}{0,628} \\
\hline literature & UDA & 52 & 0,04 & 0,194 & & & & & \\
\hline \multirow{2}{*}{$\begin{array}{l}\text { Weekly research } \\
\text { related reading hours }\end{array}$} & $\mathrm{UC}$ & 64 & 6,13 & 4,926 & \multirow{2}{*}{$-0,697$} & \multirow{2}{*}{1,776} & - 392 & 112 & 0695 \\
\hline & UDA & 50 & 6,83 & 13,087 & & & $-0,392$ & 112 & 0,095 \\
\hline Non-Spanish & $\mathrm{UC}$ & 75 & 0,15 & 0,356 & & & & & \\
\hline research reading & UDA & 54 & 0,22 & 0,420 & $-0,076$ & 0,069 & $-1,103$ & 127 & 0,272 \\
\hline English language & $\mathrm{UC}$ & 69 & 3,39 & 1,101 & & & & & \\
\hline control & UDA & 52 & 3,13 & 1,155 & 0,251 & 0,207 & 1,243 & 119 & 0,216 \\
\hline Academic & UC & 75 & 0,68 & 0,470 & -0061 & 0082 & - 742 & 127 & 0.459 \\
\hline publication & UDA & 54 & 0,74 & 0,442 & $-0,001$ & 0,002 & $-0,142$ & 121 & 0,459 \\
\hline Enough access to & $\mathrm{UC}$ & 66 & 0,55 & 0,502 & & & & & \\
\hline literature & UDA & 50 & 0,40 & 0,495 & 0,145 & 0,094 & 1,555 & 114 & 0,123 \\
\hline Enough access to & $\mathrm{UC}$ & 50 & 0,38 & 0,490 & & & & & \\
\hline digital literature & UDA & 46 & 0,22 & 0,417 & 0,163 & 93 & 3 & 94 & 0,085 \\
\hline University library & $\mathrm{UC}$ & 67 & 0,52 & 0,503 & 0054 & 0096 & 0567 & 112 & 0572 \\
\hline usage & UDA & 47 & 0,47 & 0,504 & , & ט, & ו & 112 & 2 וכ, \\
\hline
\end{tabular}

Legend: Univ. = university; UC coded as 0, UDA coded as 1; Bachelor \& below coded as 0, Master \& above coded as 1; $\mathrm{N}=$ number; $\mathrm{M}=$ mean; $\mathrm{SD}=$ standard deviation; $\mathrm{MD}=$ mean difference; $\mathrm{SEd}=$ standard error difference; $\mathrm{t}=\mathrm{t}$-value; $\mathrm{df}=$ degrees of freedom; $\mathrm{p}=$ sigma (2-tailed).

Table 7. Research related activities: Comparison between genders (male vs. female).

\begin{tabular}{|c|c|c|c|c|c|c|c|c|c|}
\hline Descriptive variables & Univ. & $\mathrm{N}$ & $\mathrm{M}$ & SD & MD & SEd & $\mathrm{t}$ & $\mathrm{df}$ & $\mathrm{p}$ \\
\hline $\begin{array}{l}\text { Taken research } \\
\text { methods course }\end{array}$ & $\begin{array}{l}\text { UC } \\
\text { UDA }\end{array}$ & $\begin{array}{l}75 \\
47\end{array}$ & $\begin{array}{l}0,49 \\
0,64\end{array}$ & $\begin{array}{l}0,503 \\
0,486\end{array}$ & 0,145 & 0,092 & $\begin{array}{r}- \\
1,569\end{array}$ & 120 & 0,119 \\
\hline $\begin{array}{l}\text { Taken research } \\
\text { methods course }\end{array}$ & $\begin{array}{l}\text { UC } \\
\text { UDA }\end{array}$ & $\begin{array}{l}71 \\
45 \\
\end{array}$ & $\begin{array}{l}0,72 \\
0,64 \\
\end{array}$ & $\begin{array}{l}0,453 \\
0,484\end{array}$ & 0,074 & 0,089 & 0,833 & 114 & 0,406 \\
\hline $\begin{array}{l}\text { Personal need for } \\
\text { method course }\end{array}$ & $\begin{array}{l}\mathrm{UC} \\
\mathrm{UDA} \\
\end{array}$ & $\begin{array}{l}73 \\
45 \\
\end{array}$ & $\begin{array}{l}0,15 \\
0,11 \\
\end{array}$ & $\begin{array}{l}0,360 \\
0,318 \\
\end{array}$ & 0,040 & 0,065 & 0,606 & 116 & 0,546 \\
\hline $\begin{array}{l}\text { University needs to } \\
\text { offer methods course }\end{array}$ & $\begin{array}{l}\text { UC } \\
\text { UDA }\end{array}$ & $\begin{array}{l}71 \\
45 \\
\end{array}$ & $\begin{array}{l}0,03 \\
0,09\end{array}$ & $\begin{array}{l}0,167 \\
0,288\end{array}$ & 0,061 & 0,042 & $1,439^{-}$ & 114 & 0,153 \\
\hline $\begin{array}{l}\text { Read research } \\
\text { literature }\end{array}$ & $\begin{array}{l}\text { UC } \\
\text { UDA }\end{array}$ & $\begin{array}{l}75 \\
45 \\
\end{array}$ & $\begin{array}{l}0,04 \\
0,07\end{array}$ & $\begin{array}{l}0,197 \\
0,252\end{array}$ & 0,027 & 0,041 & $\begin{array}{r}- \\
0,645\end{array}$ & 118 & 0,520 \\
\hline $\begin{array}{l}\text { Weekly research } \\
\text { related reading hours }\end{array}$ & $\begin{array}{l}\text { UC } \\
\text { UDA }\end{array}$ & $\begin{array}{l}71 \\
42 \\
\end{array}$ & $\begin{array}{l}6,79 \\
5,93 \\
\end{array}$ & $\begin{array}{r}10,874 \\
6,298 \\
\end{array}$ & 0,860 & 1,839 & 0,468 & 111 & 0,641 \\
\hline $\begin{array}{l}\text { Non-Spanish } \\
\text { research reading }\end{array}$ & $\begin{array}{l}\text { UC } \\
\text { UDA }\end{array}$ & $\begin{array}{l}76 \\
52\end{array}$ & 0,16 & $\begin{array}{l}0,367 \\
0,398\end{array}$ & 0,034 & 0,068 & 0,503 & 126 & 0,616 \\
\hline $\begin{array}{l}\text { English language } \\
\text { control }\end{array}$ & $\begin{array}{l}\text { UC } \\
\text { UDA }\end{array}$ & $\begin{array}{l}75 \\
45 \\
\end{array}$ & $\begin{array}{l}3,33 \\
3,24 \\
\end{array}$ & $\begin{array}{l}1,070 \\
1,190\end{array}$ & 0,089 & 10 & 0,422 & 118 & 0,674 \\
\hline $\begin{array}{l}\text { Academic } \\
\text { publication }\end{array}$ & $\begin{array}{l}\text { UC } \\
\text { UDA }\end{array}$ & $\begin{array}{l}76 \\
52\end{array}$ & $\begin{array}{l}0,72 \\
0,67\end{array}$ & $\begin{array}{l}0,450 \\
0,474\end{array}$ & 0,051 & 0,083 & 0,612 & 126 & 0,542 \\
\hline $\begin{array}{l}\text { Enough access to } \\
\text { literature }\end{array}$ & $\begin{array}{l}\mathrm{UC} \\
\mathrm{UDA}\end{array}$ & $\begin{array}{l}72 \\
44 \\
\end{array}$ & $\begin{array}{l}0,51 \\
0,43 \\
\end{array}$ & $\begin{array}{l}0,503 \\
0,501\end{array}$ & 0,082 & 0,096 & 0,854 & 114 & 0,395 \\
\hline $\begin{array}{l}\text { Enough access to } \\
\text { digital literature }\end{array}$ & $\begin{array}{l}\text { UC } \\
\text { UDA }\end{array}$ & $\begin{array}{l}57 \\
38 \\
\end{array}$ & $\begin{array}{l}0,30 \\
0,32\end{array}$ & $\begin{array}{l}0,462 \\
0,471\end{array}$ & $\begin{array}{r}- \\
0,018\end{array}$ & 0,097 & $\begin{array}{r}- \\
0,180\end{array}$ & 93 & 0,858 \\
\hline $\begin{array}{l}\text { University library } \\
\text { usage }\end{array}$ & $\begin{array}{l}\text { UC } \\
\text { UDA }\end{array}$ & $\begin{array}{l}71 \\
42\end{array}$ & $\begin{array}{l}0,52 \\
0,48\end{array}$ & $\begin{array}{l}0,503 \\
0,505\end{array}$ & 0,045 & 0,098 & 0,458 & 111 & 0,648 \\
\hline
\end{tabular}

Legend: Univ. = university; UC coded as 0, UDA coded as 1 ; Bachelor \& below coded as 0 , Master \& above coded as 1; $\mathrm{N}=$ number; $\mathrm{M}=$ mean; $\mathrm{SD}=$ standard deviation; $\mathrm{MD}=$ mean difference; $\mathrm{SEd}=$ standard error difference; $\mathrm{t}=\mathrm{t}$-value; $\mathrm{df}=$ degrees of freedom; $\mathrm{p}=$ sigma (2-tailed). 


\section{The effect of education level}

When analyzing whether the research behaviors of professors with higher levels of education were significantly different from those with lower levels of education, the study only found two significant differences: those with higher education levels were significantly more likely to have taken a research methods course inside and outside the university, as was to be expected since those tend to be part of graduate level curricula (see Table 8). However, the more striking finding was that no other significant differences in research productivity or behavior were observed. Professors with graduate degrees did not do more research.

Table 8. Research-related activities: Comparison between education levels (Bachelor \& below vs. Master \& above).

\begin{tabular}{|c|c|c|c|c|c|c|c|c|c|}
\hline Descriptive variables & Univ. & $\mathrm{N}$ & $\mathrm{M}$ & SD & $\mathrm{MD}$ & SEd & $\mathrm{t}$ & $\mathrm{df}$ & $\mathrm{p}$ \\
\hline Taken a research & $\leq$ & 44 & 0,70 & 0,462 & & & & & \\
\hline methods course & $\geq$ & 75 & 0,45 & 0,501 & 0,251 & 0,092 & 2,717 & 117 & 0,008 \\
\hline $\begin{array}{l}\text { Taken research } \\
\text { methods course }\end{array}$ & $\begin{array}{l}\leq \\
\geq\end{array}$ & $\begin{array}{l}42 \\
71\end{array}$ & $\begin{array}{l}0,81 \\
0,62\end{array}$ & $\begin{array}{l}0,397 \\
0,489\end{array}$ & 0,190 & 0,089 & 2,132 & 111 & 0,035 \\
\hline
\end{tabular}

Legend: Univ. = university; UC coded as 0, UDA coded as 1; Bachelor \& below coded as 0, Master \& above coded as 1; $\mathrm{N}=$ number; $\mathrm{M}=$ mean; $\mathrm{SD}=$ standard deviation; $\mathrm{MD}=$ mean difference; $\mathrm{SEd}=$ standard error difference; $\mathrm{t}=\mathrm{t}$-value; $\mathrm{df}=$ degrees of freedom; $\mathrm{p}=$ sigma (2-tailed).

Further analysis of research behaviors

A final analysis was done based on appointment level (principal vs. agregado vs. auxiliar) by means of Analysis of Variance (ANOVA). As Table 9 shows a few significant differences were observed: those who had principal appointments were significantly less likely to read research literature in another language than auxiliaries; agregados were significantly less likely to subscribe to academic publications than principals and auxiliaries, and agregados felt significantly less positive about access to digital literature than auxiliaries (see Table 9). No other significant differences were observed.

Table 9. Multiple comparisons among 3 appointment levels.

\begin{tabular}{|c|c|c|c|c|c|}
\hline \multirow{2}{*}{ Descriptive variables } & \multicolumn{2}{|c|}{ Appointment level } & \multirow{2}{*}{$\mathrm{MD}(\mathrm{I}-\mathrm{J})$} & \multirow{2}{*}{$\mathrm{SE}$} & \multirow[b]{2}{*}{$\mathrm{p}$} \\
\hline & (I) & $(\mathrm{J})$ & & & \\
\hline \multirow{6}{*}{$\begin{array}{l}\text { Have you ever read } \\
\text { research literature in } \\
\text { another language than } \\
\text { Spanish? }\end{array}$} & Principal & Agregado & 0,038 & 0,129 & 0,772 \\
\hline & & Auxiliar (*) & 0,268 & 0,133 & 0,048 \\
\hline & Agregado & Principal & $-0,038$ & 0,129 & 0,772 \\
\hline & & Auxiliar & 0,231 & 0,162 & 0,160 \\
\hline & Auxiliar & Principal (*) & $-0,268$ & 0,133 & 0,048 \\
\hline & & Auxiliar & $-0,231$ & 0,162 & 0,160 \\
\hline \multirow{6}{*}{$\begin{array}{l}\text { Do you subscribe to an } \\
\text { academic publication? }\end{array}$} & Principal & Agregado (*) & $-0,341$ & 0,140 & 0,017 \\
\hline & & Auxiliar & 0,075 & 0,144 & 0,603 \\
\hline & Agregado & Principal (*) & 0,341 & 0,140 & 0,017 \\
\hline & & Auxiliar (*) & 0,417 & 0,176 & 0,021 \\
\hline & Auxiliar & Principal & $-0,075$ & 0,144 & 0,603 \\
\hline & & Auxiliar (*) & $-0,417$ & 0,176 & 0,021 \\
\hline \multirow{6}{*}{$\begin{array}{l}\text { Do you feel you have } \\
\text { enough access to } \\
\text { digital literature in } \\
\text { your research area of } \\
\text { interest? }\end{array}$} & Principal & Agregado & $-0,193$ & 0,146 & 0,193 \\
\hline & & Auxiliar & 0,207 & 0,152 & 0,181 \\
\hline & Agregado & Principal & 0,193 & 0,146 & 0,193 \\
\hline & & Auxiliar (*) & 0,400 & 0,183 & 0,034 \\
\hline & Auxiliar & Principal & $-0,207$ & 0,152 & 0,181 \\
\hline & & Auxiliar (*) & $-0,400$ & 0,183 & 0,034 \\
\hline
\end{tabular}

Legend: * = "Yes" coded as 0, "No" coded as 1; MD = mean difference; SE = standard error; $\mathrm{p}=\operatorname{sigma}(2$-tailed). 


\section{DISCUSSION}

The major outcomes of the various analyses presented in this paper showed that a considerable majority $(64,0 \%)$ of the professors at both the University of Cuenca and the University of Azuay held advanced academic degrees (masters and doctorates); this number was significantly higher at UDA than at UC. The study found that professors taught an average of about sixteen hours a week, with professors at UDA teaching significantly more than professors at UC. Almost all of the respondents $(92,6 \%)$ stated they engaged in reading related to the courses they taught and that they spent about ten hours per week on reading materials related to teaching. Those with higher education levels did not read more in preparation of classes than their peers with lower education levels, and neither appointment level nor time teaching had any significant impact on reading behaviors.

In looking at the professors' research preparation and behaviors, it was found that less than half $(42,6 \%)$ of the respondents had taken a research methods course outside the university, a number that decreased to $27,9 \%$ when it came to methods courses taken inside the university. A large majority $(79,1 \%)$ felt that they needed a methods course, with even more respondents $(85,3 \%)$ stating the university needed to offer such courses. Textbooks, academic articles and on-line materials were the most commonly read forms of research-related literature. A large majority of respondents $(82,2 \%)$ read research literature in languages other than Spanish; 76,8\% of the respondents stated their English language skills ranged from "reasonable" to "fluent;" with $23,2 \%$ of the respondents reported their English language skills were poor or non-existent.

When it came to research and publication activities, $44,4 \%$ of the respondents stated they had done a conference presentation or written a non-academic article and only $24,8 \%$ stated they had published a refereed article. Very few of them had written a book review $(14,0 \%)$ or had served as a reviewer for a refereed journal $(11,7 \%)$. UDA professors stated they had better access to literature and on-line sources than their peers at UC. University library usage was less than $50 \%$ overall $(44,2 \%)$, with again slightly higher numbers for UDA professors. On average, professors in the survey spent 5,7 hours a week on research. UC professors spent 6,1 hours on research related activities and UDA professors spent 5,1 hours on research.

What was not surprising with regard to research behaviors was that professors with advanced degrees had taken significantly more research methods courses (both inside and outside the university) since such courses tend to be part of a graduate degree program of studies. Very surprising, however, was that the comparative analyses did not find any significant differences based on university origin or gender. Even more revealing was the fact that there was no significant difference in research productivity or behavior between professors with and professors without advanced degrees, and perhaps this study is more interesting because of what it did not find than for what it found.

\section{CONCLUSION}

What can be concluded from this exploratory investigation and what suggestions can be made? For Ecuador's universities and professors to reach a level at which research and teaching are mutually supportive rather than mutually exclusive and research quality and quantity are greatly enhanced, improvement efforts need to be comprehensive, far-reaching and different from what has been done so far. They should include professors, administrators, graduate and undergraduate students and should be related to all three components of the university's mission: teaching, research and service. It is imperative for research to become an integral part of academia in the country so that it will eventually be able to assist decision makers in addressing society's pressing needs and to advance learning and theory.

This study found that a majority of the respondents held master or doctoral degrees, yet also found that research output was low and that professors with advanced degrees did not produce significantly more research than their peers without advanced degrees. This finding raises several interesting questions: if professors have taken research methods courses and have completed a 
master's thesis or even a doctoral dissertation, why is it that their research productivity is so low and why is it that they hardly publish? Is it because they teach too much and have no time? What is the quality of the research preparation they receive in their graduate degree programs? Do professors take graduate programs that are non-demanding and just lead to a degree, rather than programs that are demanding and teach them how to do research? Is there a lack of resources and support? Is the research infrastructure inadequate? Is research undervalued as compared to teaching? Do professors who hold $\mathrm{PhD}$ degrees not take on research leadership roles but rather end up in administrative positions where they are not expected to do any research? Why is it that, whereas these respondents state they spend about 6 hours a week on research-related activities, the University of Cuenca as a whole only published 69 refereed articles in English in the period 2008 and 2012 and the University of Azuay only had 12 non-Spanish refereed articles (SCImago Research Group, 2014), while its professors hold more advanced degrees than professors at UC? The answers to many of these questions will probably be "All of the above..."

- What be done? What steps can universities and individual professors take to enhance their research output, given the limitations that presently exist? With respect to this the authors provide several suggestions, ranging from personal to institutional; some of these might be far-reaching and unconventional, yet changes need to be drastic for the situation to improve.

- Professors in need of graduate degrees should select degree programs that teach them how to do research and not just provide them with a title. Such programs will place greater demands on them and mean greater (personal) time investments. It is understandable that professors seek a quick solution to a personal need to obtain an advanced degree. Yet, as this study showed, at present those degree programs have not yet led to greater research productivity. Universities could be more demanding in the graduate programs they offer and more selective in their support of researchheavy graduate programs. They should stimulate professors to attend programs that guarantee the necessary research skills and reward professors who complete more rigorous, research-based programs.

- The professors who should be the true leaders of the research effort, the ones with $\mathrm{PhD}$ degrees, have not lead effectively so far and have not set the right example for others to follow. Perhaps a paradigm shift is needed in this regard: professors with PhD's should work on their research, teach less, and perhaps not always assume that a move into administrative positions in academia is a good one. Academic administrators need to be able to value, assess and support the research efforts of others and find the resources for them to be successful, rather than do it themselves. One can wonder if academic administrators really need $\mathrm{PhD}$ degrees to do their jobs.

- Lately, Ecuador's universities have imported foreign scholars under the Prometeo program to lead the research and publication efforts and many teach research methods courses and work with local research teams. This program has met with considerable success, if those scholars actually guide and lead their peers and not do their research in a vacuum. Why could more of Ecuador PhD's not be asked to teach research methods courses to their peers and work with them on their research and publication efforts?

- Universities could consider providing professors with release time when they have a worthwhile research project. Release time enables professors to exchange time in the classroom for time to do research. Research and teaching should be treated equally and an evaluation and reward system should be in place that recognizes both efforts fairly. All over the world professors do research, publish and teach; some teach more than others and some do mostly research which is an outflow of their prior education, personal interests and skill sets. Yet, all of them work under systems that are commonly accepted as fair and equitable. Why not in Ecuador?

- Universities should consider reducing the teaching load of those professors with the proper education and the right inclination for research, even considering taking them somewhat out of the classroom. If professors teach sixteen to twenty hours a week and have several other job-related responsibilities, they have little or no time to do research, regardless of how well they are educated or how passionate they are about research. This is not favoritism; it is applying the right resources to the right effort in order the address the right needs. 
- Ultimately, the country could then move to a system where there are different faculty positions and there would be research professors and teaching professors, with different responsibilities and different measures of success, yet all of them would be working together for the good of the student, the university and the country.

It needs to be emphasized again that the survey which provided the data for this study was selfadministered; the researchers had to trust that the respondents would answer the questions truthfully and that the data accurately reflected such issues as faculty reading and research behaviors and control of the English language. Adding up the time spent on various activities such as teaching, reading for courses and research, and conducting research, professors at UC reported they spent about 40 hours a week on those activities and professors at UDA spent about 46 hours. Given that teaching hours are set and that the professors' administrative (and possibly professional consulting activities) also take up a lot of time, there might have been a bias towards over-reporting reading and research activities and that activities which were reported as "research-related" did not qualify as such. This assumption is supported by the fact that research productivity at both universities was very low, even though professors reported spending 5-6 hours a week on research activities and an additional 6 hours on research-related reading.

This exploratory study raised more questions than it provided answers. It is merely a snapshot of reading and research behaviors among professors in a private and a public university in one town in Ecuador, yet since these universities represented the "middle of the pack" in research productivity nationally according to SCImago, some of the trends identified are indicative of academia in Ecuador as a whole. Ecuador's government has set challenging goals for its professors and its universities and the research environment in the country will undoubtedly change somewhat over time. Yet, so much more is possible within the limitations that presently exist if administrators, professors and government officials would be willing to look at the issue a little differently. Mandates hardly ever work effectively and suggestions are often more successful. Perhaps the suggestions made in this paper could be helpful as a starting point for further discussion, and if not at the national level than certainly at the university level. Somehow, the old paradigms need to be shifted and often it only takes a few examples and success stories to get the ball rolling. Could the University of Azuay and the University of Cuenca be those examples?

\section{REFERENCES}

Bellas, M., R. Toutkoushian, 1999. Faculty time allocation and research productivity: Gender, race and family effects. Rev. High. Educ., 22(4), 367-390.

Buela-Casal, G., M. Bermudez, J. Sierra, R. Quevedo-Blasco, A. Castro, A. Guillen-Riquelme, 2012. Ranking de 2011 en producción y productividad en investigación de las universidades españolas. Psicothema, 24(4), 505-515.

Blackburn, R., J. Lawrence, J. Bieber, L. Trautvetter, 1991. Faculty at work: Focus on teaching. Res. High. Educ., 32(4), 363-383.

Bland, C., B. Center, D. Finstad, K. Risbey, J. Staples, 2005. A theoretical, practical, predictive model of faculty and department research productivity. Acad. Med., 80(2), 225-237.

Chen, Y., A. Gupta, L. Hoshower, 2004. Faculty perceptions of research rewards. J. Coll. Teach. Learn., 1(12), 1-13.

Chen, Y., A. Gupta, L. Hoshower, 2006. Factors that motivate business faculty to conduct research: An expectancy theory analysis. J. Educ. Bus., 81(4), 179-189.

Chen, Y., Q. Zhao, 2013. Differences in business faculty's research motivation. J. Educ. Bus., 1, 255282.

Delgado, F., R. Fernandez-Llera, 2012. Sobre la evaluación del profesorado universitario (especial referencia a ciencias económicas y jurídicas). Revista Española de Documentación Científica (35) $2,361-375$. 
Dirección de Talento Humano (2013). Sistema de portafolio del personal universitario Universidad de Cuenca.

Dundar, H., D. Lewis, 1998. Determinants of research productivity in higher education. Res. High. Educ., 39(6), 607-631.

Feyen, J., H. Van Hoof, 2013. An analysis of the relationship between higher education performance and socio-economic and technological performance indicators: A Latin-American case study. Maskana-Revista Cientifica, 4(2), 1-20.

Fien, F., 2000. To what degree does the desire for promotion motivate faculty to perform research? Testing the expectancy theory. Res. High. Educ., 41(6), 723-752.

Fien, F., 2008. What kind of faculty are motivated to perform research by the desire for promotion? High. Educ., 55(1), 17-32.

Fien, F., R. Blackbrun, 1996. Faculty rank system, research motivation and faculty research productivity: Measure refinement and theory testing. J. High. Educ., 67(1), 2-22.

Ferrari, C., N. Contreras, 2008. Universidades en América Latina. Nueva Sociedad, 218, 23-38.

Hasselback, J., A. Reinstein, E. Schwan, 2000. Benchmarks for evaluating the research productivity of accounting faculty. J. Account. Educ., 18(2), 79-87.

Hekelman, F., S. Zyzanski, S. Flocke, 1995. Successful and less-successful research performance of junior faculty. Res. High. Educ., 36(2), 235-255.

Long, R., A. Crawford, M. White, K. Davis, 2008. Determinants of faculty research productivity in information systems: An emperical analysis of the impact of academic origin and academic affiliation. Scientometrics, 78(2), 231-260.

Olivas-Avila, J., B. Musi-Lechuga, A. Guillen-Riquelme, A. Castro, 2012. Diferencias en la producción investigadora en tesis y artículos de los profesores funcionarios de psicología en España en función del sexo. Anales de Psicologia, 28(2), 597-603.

Perry, R., R. Clifton, V. Menec, C. Struthers, R. Menges, 2000. Faculty in transition: A longitudinal analysis of perceived control and type of institution in the research productivity of newly hired faculty. Res. High. Educ., 41(2), 165-194.

Prince, M., R. Felder, R. Brent, 2007. Does faculty research improve undergraduate teaching? An analysis of existing and potential synergies. J. Eng. Educ., 96(4), 283-294.

Sa, C., 2008. Interdisciplinary strategies in U.S. research universities. High. Educ., 55 (5), 537-552.

Sax, L., L. Hagedorn, M. Arredondo, F. Dicrisi, 2002. Faculty research productivity: exploring the role of gender and family-related factors. Res. High. Educ., 43(4), 423-446.

SCImago Research Group (2014). SIR Iber Ecuador Report. Retrieved March 16, 2014. Downloaded from http://www.scimagoir.com in November 2013.

Sierra, J., G. Buela-Casal, M. Bermudez, P. Santos-Iglesias, 2009. Productividad académica en la investigación de postgrado. Psicothema, 21(1), 124-132.

Smeby, J., S. Try, 2005. Departmental contexts and faculty research activity in Norway. Res. High. Educ., 46(6), 593-619.

Taylor, M., E. Locke, C. Leer, M. Gist, 1984. Type A behavior and faculty research productivity: What are the mechanisms? Organ. Behav. Hum. Perf., 34(3), 402-418.

Teodorescu, D., 2000. Correlates of faculty publication productivity: A cross-national analysis. High. Educ., 39(2), 201-222.

Van Hoof, H., M. Estrella, M. Eljuri, L. Torres, 2013a. Ecuador's system of higher education in times of change. JHHE, 12(4), 345-355.

Van Hoof, H., A. Sharma, J. Moon, M.A. Galarza Cordero, K. Farfán Pacheco, 2013b. Student reading behaviors and preferences at public and private universities in Ecuador: A comparative study. MASKANA-Revista Cientifica, 4(1), 1-15.

Williamson, I., D. Cable, 2003. Predicting early career research productivity: The case of management faculty. J. Organ. Behav., 24(1), 25-44. 